\title{
Web-Quest Technology as a Tool of Teaching English
}

\author{
Yuliya KAMARDINA \\ Ph.D. (in Philology) \\ Associate Professor \\ Department of Foreign Languages \\ Balashov Institute of Saratov State University \\ 26 K, Marx str., Balashov, 412300, Russia \\ $+78454542525$ \\ kamardina-yuliya@mail.ru
}

\begin{abstract}
This article is devoted to the current issue of using educational Internet technologies in the subject field 'English language'. Special attention is paid to the use of innovative technology 'web-quest' in the educational process, which provides high-quality learning of the main English sections: listening, reading, speaking, writing, since Internet resources contain differentiated educational information, as well as numerous tools for their perception. The purpose of the work is to identify the effectiveness of the use of educational Internet technology 'web quest' in English lessons in educational organizations. English lessons in the form of a web quest are productive and effective, and implement the main direction in education - a person-oriented approach to students and the educational process.

The article provides evidence of the effectiveness of using modern information technologies in English lessons, which increase the effectiveness of students learning material, make the learning process more diverse, and the educational material accessible and interesting.
\end{abstract}

Keywords: Internet resources; modern information technologies; technology 'web-quest'; computerization of the educational process; web tasks.

\section{Introduction}

The Internet has rapidly entered the education system and is actively used in teaching a foreign language (Kamardina, 2019). Currently, one of the main tasks of educational organizations is to 
prepare students for the development of the information culture and orientation in the flow of information on the Internet. At the present stage of teaching, the importance of using Internet resources in the learning process is emphasized. The teacher gets the opportunity to apply not only explanatory traditional teaching, but also use Internet technologies, and students - to own a variety of information, to be independent in the educational process. The introduction of new information using Internet resources is fast and efficient.

Since the requirements for the modern lesson have significantly increased and continue to grow, today every teacher tries to make his lesson as bright and interesting as possible. Therefore, it is necessary to use modern information technologies in education, providing unlimited access to knowledge sources via the Internet, electronic reference books and encyclopedias, paintings and films. Lessons using computer telecommunications become more productive, informative, and effective. Information technologies contribute to the activation of cognitive activity, the disclosure and development of individual abilities of students (Kamardina, 2017), allow to implement modern trends in education (Begaly, 2017).

The Internet provides access to an unlimited amount of information, makes it possible to use the language in real communication, to acquire regional geographic knowledge, to replenish the vocabulary, to study the peculiarities of speech etiquette of native speakers, as well as to improve your skills in educational and cognitive activities. Internet resources are the base that teachers use to solve various didactic tasks. The use of Internet resources in teaching a foreign language helps to form a foreign language communicative competence.

The main purpose of this article is an attempt to identify the effectiveness of using the latest technologies in English lessons, one of which is the 'web-quest' technology (Kamardina, 2019). The innovative feature of this article is the emphasis on the particularities of introducing the 'web quest' educational technology into the educational process as a productive and motivational tools of mastering the English language.

\section{Methods}

The main research methods are the descriptive method and the method of systematizing the theoretical foundations of the computerization of the educational process in the subject field 'English language'. The object of the research is modern Internet technologies used in the educational process, the subject of research is the educational technology 'web-quest'.

Literature review. The work is based on the works of scientists in the field of modern information technology and methods of teaching a foreign language. To date, the greatest interest is caused by the pedagogical information and communication technologies, which are engaged in Panfilova 
(2009) and Polat (2007). Special attention is paid to the innovative web quest technology, which has been integrated as an educational technology into the educational process by Bernie Dodge (2001a, 2001b, 2001c, 1995, 1999), and supplemented and expanded by Thomas March. The use of 'web quest' technology in the educational process is studied by Galustyan (2015), Shcherbina (2016), Lamb (2000-2004), Roberts (2006), and Watson (1999).

\section{Results}

Improving the educational process makes it possible to move from passive to active learning of the English language. A big role is played by the "web-quest" technology.

Web-quest is a problematic task with elements of a role-playing game. Quest is translated from English as a purposeful long-term search. This is one of the types of computer games designed for solving a specific educational problem. We- quests are a new didactic model of the educational process, which has great opportunities, changing the nature, place, methods and methodology of teaching, organizing a fundamentally new approach to solving educational problems, improving the quality, accessibility, flexibility and effectiveness of training, making it developing. Web quest technologies occupy a worthy place in learning English among the used technologies, as they do not require special technical knowledge. This is an easy way to work on the Internet (Bobrovskikh, 2008).

When using web-quest technology in teaching a foreign language, teachers simultaneously solve a number of tasks, such as the implementation of collective and individual activities, increasing motivation to learn language, expanding language knowledge, forming an integral system of knowledges, skills and abilities aimed at personal development (Begaly, 2017).

Web-quests allow you to implement visibility (various types of demonstrations), multimedia (sound video and animation effects) and interactive learning (disclosure of students' abilities).

Web quests increase students' motivation through:

- multimedia (psychoemotional attitude). The introduction of game forms and illustrations contribute to the formation of positive emotions and success in work;

- modality. The extensive use of sensory channels gives a real idea of the object when objects are not available, that is, the material is visualized;

- word-image. It is used for comparison and generalization, the information is displayed in the shortest possible time; 
- structured presentation of educational material. It allows students to build a learning path, independently adjust the amount of information, build clear logical connections, which leads to a holistic understanding of the task;

- activation of teacher' and student' research activities. Information search and processing contribute to the formation of students' information and communication skills;

- the results of the work are carried out in stages, the assessment becomes visual, and the reflection becomes conscious.

Creating a web-quest is a long and complex process that requires creative and analytical thinking from the developer. High professionalism is required from the teacher in the process of developing and applying web-quest technology.

At the beginning on a web-quest working, the teacher creates a specific problem situation that should arouse students' interest and encourage them to find a solution to this problem. It is necessary to take into account various aspects: the content of the material, its role in the study of a specific subject area, the value of the information received. When developing a web-quest, you need to pay attention to the connection of web-tasks with the material being studied, and the ease of passing information sites. The Internet allows students to study the problem from different angles, analyze and synthesize information, and consider the issue in a broader sense. A well-designed web- quest makes the process of learning a foreign language more interesting and effective (Shcherbina, 2016).

The teacher when developing web-quests, should anticipate possible problems that may arise when implementing the quest in the educational process and ways to solve them. After the topic decision, the teacher selects the material on the Internet. You should use optimal search terms that take into account the correct word order in the request for information on the network. This request is aimed at getting sites that allow students to find the necessary information in a short period of time. When finding sites, the teacher should check them for scientific validity before providing them to students. There are several ways to find verified information on websites: a teacher can use a special site called Teachers First, where various lessons are collected, links to educational resources are provided, and so on. This site provides a systematic training material, which is convenient and helps the teacher not to spend a lot of time searching. It is also possible to use certain educational resources, such as http://www.study.ru where there are online lessons in English at different levels from simple to complex, a basic guide to English grammar, various courses, video lessons, discussions (Tuzhikova, 2015).

There are three types of web-quests: 
- by duration (short-term and long-term);

- by content (single-project and intersubject);

- by type of task (retelling, resolving disputes, etc.).

Web-quests allow you to perform the following tasks:

- disciplining - involvement in the learning process, identification of skills and abilities;

- developing - development of creative abilities, interests, expanding horizons, skills of independent search and research activities;

- educational - education of tolerance and responsibility.

When learning a foreign language, web-quests create a natural language environment where various types of speech activities are taught: speaking, listening, reading and writing.

The teacher using-web quests in the educational process, makes it possible to learn basic knowledge, systematize the gained knowledge, form learning motivation, and also provides students with educational and methodological assistance in independent study of the material (Galustyan, 2015).

The teacher's work with the web-quest consists of two stages.

The first stage. Preliminary preparation:

- determining the type of web-quest (a short-term 1-3 lessons or a long month-quarter);

- individual or group;

- end result. The selection of resources.

The second stage. Design a web-quest in phases, following a clear structure:

- introduction - familiarizing students with the proposed topic, sections and their motivation;

- task - a clear statement of goals and objectives, conditions for implementation, solutions, achieving the final result, reporting form;

- process - strict compliance with the stages of work, the distribution of responsibilities for each student, the use of auxiliary materials recommended for completing tasks;

- reaching consensus - clear criteria and parameters for evaluation using forms;

- conclusion - the results that students should come to when completing tasks in the web- quest, summing up and defending; 
- materials -used-links to the necessary training resources;

- comments for the teacher - guidelines for teachers who will use the web-quest.

The introduction should have a cognitive value, the tasks should be clearly formulated and consistent, the resources should be diverse, and the assessment should be adequate.

Web-quest technologies make it possible to learn more productive. Students do not need to spend a lot of time searching for new information on the Internet, as the teacher gives them a list of websites on a given topic to solve educational problems (Medvedeva, 2016).

Web-quests are active in learning English and are aimed at independent activity of students, in the process of which information and communication competencies are formed.

Students through web-quests get the opportunity to work in an optimal mode, interrupt training or return to what they have completed, get the necessary help, overcome the psychological barrier of uncertainty, and work out their skills and knowledge to the desired level (Mishchuk, 2016).

\section{Discussion}

Web-quest technology has its advantages and disadvantages. Let's highlight the advantages:

- targeted research;

- individual and group work;

- making independent decisions;

- development of self-education skills, communication competence, and thinking abilities;

- students become more responsible;

- reducing the language barrier;

- motivation of students to learn new language material;

- development of critical thinking, that is, the student transforms the collected information, which increases the productivity of activities.

Difficulties include:

- the need for high-speed Internet access;

- computer literacy of both teachers and students.

Thus, working on a web-quest, students become more active, independent, find their own way to assimilate knowledge, and the teacher only organizes and stimulates the learning process. 
The web-quest has several types of tasks: retelling, planning and designing, self-discovery (personality research), compilation, creative task, analytical task (search and systematization), detective, puzzle, mysterious story (conclusions based on contradictory facts), consensus building, assessment (point of view), journalistic investigation (objective presentation of information), persuasion, scientific research.

The results of a web-quest can be presented in the form of a presentation, creating a webpage or website, an oral presentation, an essay, etc. (Nezgovorova, 2017).

The topic of the web-quest should be interesting for students, it is a game in which roles are distributed, tasks with instructions for completion, final results and acceptable grades are identified.

Web-quest stages:

Stage 1. The definition of the topic. The topic must meet state standards, tasks can develop students' thinking and complement the learning material received in the lesson.

Stage 2. Finding a template for creating a web-quest.

Stage 3. Thinking through the form of tasks.

Stage 4. Thinking through the options assessment.

Stage 5. Finding sites where students will find information (Shaikhullina, 2016).

Thus, the search and processing of information through web-quest technology develops students' thinking, ability to analyze and synthesize, as well as assessment and self-assessment. Working with the web-quest, students experience real situations, make their own decisions, learn to synthesize, analyze, compare independently obtained information, evaluate their work and find ways to correct errors. Their activities become free, which leads to productivity and efficiency.

\section{Conclusion}

In this work, the use of Internet technologies in English lessons was considered and it was revealed that Internet resources form students' interest in foreign language activities and generate the need to learn a foreign language, communicate in it, they make it possible to switch from passive to active English learning.

The results of the study showed that a properly designed web-quest makes the process of learning English more interesting and effective, and expands the innovative and creative potential of students. This is an easy, interesting and effective way to work on the Internet. Elements of role- 
playing games motivate students to learn the language and give them the opportunity to develop their knowledge to a high-quality level.

The results of this study can be used in the process of teaching English in educational organizations.

\section{References}

Begaly, M.B. (2017). Application of educational Internet resources in the process of teaching English. Young scientist, 10, 13-15. (in Russian)

Bobrovskikh, O.N. (2008). Use of web-quests in training (on the example of the English language). Retrieved from: http://www.eidos.ru/journal/2008/1216.htm (Accessed on December 20, 2019). (in Russian)

Dodge, B. (1995). Some Thoughts About WebQuests. Retrieved from: http://webquest.sdsu.edu/about_webquests.html (Accessed on December 10, 2019).

Dodge, B. (1999). Web Quest Taskonomy: A Taxonomy of Tasks. Retrieved from: http://webquest.sdsu.edu/taskonomy.html (Accessed on December 10, 2019).

Dodge, B. (2001a). Creating A Rubric for a Given Task. Retrieved from: http://projects.edtech.sandi.net/staffdev/tpss99/rubrics/rubrics.html (Accessed on December 10, 2019).

Dodge, B. (2001b). A Rubric for Evaluating WebQuests. Retrieved from: http://webquest.sdsu.edu/webquestrubric.html (Accessed on June 4, 2019).

Dodge, B. (2001c). Focus: Five rules for writing a great WebQuest. Learning and Leading with Technology, 28(8), 6-9.

Galustyan, O.V. (2015). The practice of using web-quests in teaching English as a foreign language. VSU Bulletin, 2, 115-121. (in Russian)

Kamardina, Y.S. (2017). The teaching of reading at the primary level of General education with the use of information technologies at the lessons of English. Actual problems of teaching in primary schools. Kiryushkin readings: mater. All-Russian scientific and practical Conference 29-30 March 2017, 141-144. (in Russian)

Kamardina, Yu.S. (2019). Technology development of "web-quest" in the study of the English language. Scientific journal "Discourse", 6(32), 90-96. (in Russian) 
Lamb, A. (2000-2004). Locate and Evaluate WebQuests. EduScapes. Teacher Tap. Internet resourses. Webquests. Retrieved from: http://eduscapes.com/tap/topic4.htm (Accessed on December 10, 2019).

March, T. (1995-2001). What's on the Web? Sorting Strands of the World Wide Web for Educators. Retrieved from: http://www.ozline.com/learning/webtypes.html (Accessed on December 15, 2019).

March, T. (1997-2001). Working the Web for Education. Theory and Practice on Integrating the Web for Learning. Retrieved from: http://www.ozline.com/learning/theory.html (Accessed on December 15, 2019).

March, T. (1998). Web-Quests for Learning. Retrieved from: http://www.ozline.com/webquests/intro.html (Accessed on December 15, 2019).

March, T. (2002-2003). Criteria for Assessing Best WebQuests. Retrieved from: http://www.bestwebquests.com/bwq/matrix.asp (Accessed on December 10, 2019).

March, T. (2003). The learning power of webquests. Educational Leadership, 61(4), 42-47.

Medvedeva, Y.S. (2016). Application of Web-quest technology as a modern model of training. Young scientist, 17, 136-139. (in Russian)

Mishchuk, O.N. (2016). Web quest technology as an integration of motivational and communicative aspects in teaching foreign languages. Scientific and methodological electronic journal "Concept", 5, 168-171. (in Russian)

Nezgovorova, E.Yu. (2017). Web quest in foreign language lessons as a method of project activity. Scientific and methodological electronic journal "Concept", 33, 39-43. (in Russian)

Panfilova, A.P. (2009). Innovative pedagogical technologies: Active learning: textbook. manual for students. higher. studies'. Institutions. Moscow: publishing center "Academy". (in Russian)

Polat, E.S. (2007). Modern pedagogical and information technologies in the education system: textbook. manual for University students. studies'. Institutions. Moscow: publishing center "Academy". (in Russian)

Roberts, L. (2006). The WebQuest Creation Process: A Case Study of Preservice Teachers Working Individualistically or Collaboratively. Proceedings of Society for Information Technology \& Teacher Education International Conference 2006, 1760-1767.

Shaikhullina, A.I. (2016). The use of technology web quest on the English language. Priority 
directions of development of science and education: materials of the VIII international conference. scientific-practical Conference (Cheboksary, January 29, 2016), 1(8), 208-212. (in Russian)

Shcherbina, A.N. (2016). Web quest - as an innovative technology in the system of implementation of the Federal state budget. Science and prospects, 4, 1-7. (in Russian)

Tuzhikova, E.S. (2015). Information and communication technologies in modern education. Humanities, socio-economic and social Sciences, 4, 296-299. (in Russian)

Watson, K. (1999). WebQuests in the Middle School Curriculum: Promoting Technological Literacy in the Classroom. Retrieved from: http://www.ncsu.edu/meridian/jul99/webquest/index.html (Accessed on December 15, 2019). 